Goldschmidt 2021 Abstract

https://doi.org/10.7185/gold2021.4190

\section{Metal saturated picrites from Noril'sk - lunar equivalents?}

\author{
CHRIS BALLHAUS ${ }^{1}$, RAÚL O.C. FONSECA ${ }^{2}$, FELIPE P. \\ LEITZKE $^{3}$, THORSTEN NAGEL ${ }^{4}$ AND AHMED EL \\ GORESY $\uparrow^{5}$
}

${ }^{1}$ University of Bonn

${ }^{2}$ Ruhr-University Bochum

${ }^{3}$ Universidade Federal do Rio Grande do Sul

${ }^{4}$ Aarhus University

${ }^{5}$ Bayerisches Geoinstitut

Presenting Author: ballhaus@uni-bonn.de

The Noril'sk magmatic province hosts tholeiitic to picritic compositions that have preserved five different melts (Fig. 1): a basaltic andesite with 5 wt. $\% \mathrm{MgO}$ (1a), an $\mathrm{Fe}-\mathrm{C} \pm \mathrm{S}$ melt, $\mathrm{Fe}-\mathrm{S}$ sulfide melt $(1 \mathrm{~b})$, and in the mesostasis wedged between plagioclase laths two immiscible melts in the fayalite-leucite$\mathrm{P}_{2} \mathrm{O}_{5}-\mathrm{SiO}_{2}$ system (1c). Metal saturation occurred at $\geq 1130^{\circ} \mathrm{C}$, the liquidus temperature of the andesitic inclusion in Fig. 1a, when the picritic parent magma intruded Carboniferous coalbearing sediments and assimilated carbon. The early saturation with metallic $\mathrm{Fe}-\mathrm{C} \pm \mathrm{S}$ melt resulted in a differentiation path without much $\mathrm{SiO}_{2}$ enrichment, quite unusual for terrestrial settings. The most fractionated phase observed in the picrite is pure fayalite.

We performed fractionation experiments from 1170 to $1030^{\circ} \mathrm{C}$ with the andesitic composition, to quantify the effect of $\mathrm{fO}_{2}$ on the fractionation path. $\mathrm{fO}_{2}$ was buffered at the wüstite-magnetite (WM) and 2 log-bar units below the iron-wüstite (IW) buffer, using graphite and metallic $\mathrm{Fe}$ capsules as sample containers. Under highly reduced conditions at IW-2, the composition fractionates pyroxene and plagioclase, and derivative melts move toward the miscibility gap in the fayalite-leucite- $\mathrm{SiO}_{2}$ ternary. Two immiscible melts exsolve between 1050 and $1030^{\circ} \mathrm{C}$, one $\mathrm{FeO}-\mathrm{P}_{2} \mathrm{O}_{5}$ rich, and a second one silica enriched with up to 80 wt.\% $\mathrm{SiO}_{2}$. In experiments under oxidized conditions at WM outside Fe metal saturation, no liquid immiscibility is observed, and enrichment in $\mathrm{SiO}_{2}$ with increasing fractionation is more pronounced than with $\mathrm{Fe}$ metal saturation.

The metal saturated picrites share many similarities with low $\mathrm{TiO}_{2}$ lunar basalts. They carry oxide populations that correspond to those of lunar compositions. On the Moon, late-stage liquid immiscibility appears to be more widespread than in terrestrial compositions, and many lunar basalts carry phases enriched in $\mathrm{Cr}^{2+}, \mathrm{Ti}^{3+}$, and are $\mathrm{Fe}$ metal saturated. Lunar igneous rocks enriched in silica appear to be rare and may be related to the exsolution and large-scale segregation of immiscible silica-rich melts (Jolliff et al. 1999; Fig. 1C).

Jolliff, B.L. et al. (1999) Amer. Min. 84, 821-837.

Fig. 1. Melts in the Noril'sk picrites.

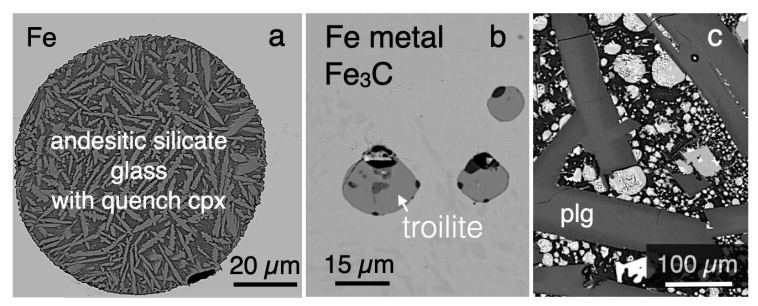

